\title{
Having a Job Is Not Enough to Escape Poverty: Case of Indonesian Working Poors
}

\author{
Financy Ramadhani ${ }^{1}$, Fajar Santoso Putra ${ }^{2}$
}

\begin{abstract}
Having a job is apparently not enough to ensure that the person is able to make ends meet, because the problem of unemployment is actually not the main problem of eradicating poverty. Poor people do not have the privilege of not working, they inevitably have to work to earn income. But the income from the work they do is of low value, so it is unable to meet their needs, especially basic needs. About 8.25 percent of working population in Indonesia are working poor, meaning they work, but the income is not enough to meet the needs. Using 2018 National Socio Economic Survey (SUSENAS) data, this study tries to dissect the labor conditions in Indonesia. The working population is still dominated by workers with low education, and there are still many who work as family/unpaid workers showing as a form of inefficiency. The characteristics of poor workers in Indonesia are male, living in rural areas. Still in prime age range, but poorly educated, only at elementary school level or less. These characteristics at the individual level are closely related to the mechanism of low wages which makes a person more at risk of becoming a working poor.
\end{abstract}

Keywords— working poor, SUSENAS, labor, poverty, Indonesia

\section{INTRODUCTION}

Job creation is often seen as one of the important ways to overcome the problem of poverty, and to achieve economic and social development in a country [1], [2]. The majority of the population depends on income derived from work to buy the goods and services they need to support their daily lives and families. Logically, people who do not have a job will have difficulty meeting their needs because they do not earn income. Therefore, the governments of countries in the world are eager to make the creation of sustainable employment as one of the focuses of their country's development [3]. Work is expected to be able to "lift" someone out of poverty, but this can only happen if the work has adequate quality, including providing sufficient income, guaranteed, and has a safe work environment.

The problem of poverty is closely related to employment. But the unemployed population is not the only group that is vulnerable to poverty, but also the population who have jobs. Poor people are rarely unemployed, they do not have enough non-labor income to survive without work. As a result they will do any work available to earn a living and meet their daily needs. In fact, some workers remain poor because the income they earned is still too low that it is not sufficient to meet the basic needs of daily life and lift them and their families out of poverty [2], [4]-[6].

${ }^{1}$ Financy Ramadhani is student at Magister of Population and Labor Economics, Faculty of Economy and Business, Universitas Indonesia, Depok, Jawa Barat, Indonesia. E-mail: firadhani@gmail.com

${ }^{2}$ Fajar Santoso Putra is student at Magister of Population and Labor Economics, Faculty of Economy and Business, Universitas Indonesia, Depok, Jawa Barat, Indonesia. E-mail: dmorphosiz@ gmail.com
These conditions indicate that working alone is not enough to get out of poverty. Priyono (2002) said that working status does not guarantee that a person will become prosperous (or at least not poor). In Indonesia in 2018, of the total population aged 15 years and over who are included in the labor force there are 8.25 percent of the population who have jobs but their per capita household expenditure is still below the poverty line [8]. This means that they have difficulty in meeting their needs even for the minimum living needs standard.

Being employed but still unable to meet the basic living needs indicates that working population are as vulnerable to unemployed population in terms of poverty. This demanded the government to not only pursue as many job opportunities as possible, but rather to create productive employment opportunities that provide decent wages/salaries so workers and their families are not vulnerable to poverty [1]. Just as governments in many countries, the Indonesian government has started to recognize and try to meet these challenges, among others through the National Long-Term Development Plan 20052025, and by implementing the Decent Work Framework For All that specifically becomes the eighth goal in the Goal Sustainable Development (Sustainable Development Goals).

\section{LITERATURE REVIEW}

Adapting Amartya Sen's ideas, the World Bank (2000) defines poverty as a "loss" of welfare, which is a function of "capability" in society. There is no universally accepted explanation regarding the definition of poverty. In general, the definition of poverty can be divided into three approaches, absolute poverty, relative poverty, and subjective poverty. The third term is the most easily defined, a person will be classified as poor as long as he feels that he does not have enough wealth. However, in academic and public discussions this term is the most rarely used [10]. Relative poverty is usually the result of inequality in the distribution of income / expenditure of the population [8], and is very dependent on the living conditions of a country at a certain time. There will always be residents who are categorized as poor if using this measure. Meanwhile, the definition of poverty which is the most widely used is absolute poverty. Poverty is measured using a minimum standard of living to meet basic daily needs, in the form of food and non-food needs. The standard commonly used to measure absolute poverty is the poverty line.

Badan Pusat Statistik (BPS) routinely calculates poverty lines using the concept of ability to meet basic living needs. A person is considered poor if he is unable from an economic standpoint to meet the basic needs of daily life in the form of food and non-food needs, measured in terms 
of expenditure [8]. The expenditure approach is used as the income approach with the reason that households are more precise in reporting the amount of expenditure than when reporting the amount of income. Expenditures to be compared with the poverty line are per capita expenditure, which is the total expenditure of all household members divided by the number of household members. This study uses per capita expenditure as a per capita income approach because in Indonesia usually the income earned in a household will be used jointly by all members who live together in that household.

Being employed but not being able to meet the basic needs of life are often referred to as working poor. Gammarano (2019) describes worker poverty as a condition faced by someone who works (and is paid), but the income received is not enough to meet their daily needs and family, and to get out of poverty. According to [11], poor workers are people who work with personal income below a certain threshold. This threshold can be set in the form of a poverty line, a certain percentage of average wages received by workers in general, minimum wages, and others. In this study, the working poor is defined as someone who is working but still living in households below the poverty line [6], [12].

From previous research on the characteristics of workers and their relationship with poverty status, it can be concluded that there are at least three mechanisms that connect the two [2], namely (1) low income, (2) low occupational participation in the household sector, and (3) high costs arising from the existence of household members who become dependents [13], [14]. This mechanism is influenced by variables at the macro level and at the micro level. Variables at the macro level are labor market institutions and rules [15], while variables at the micro level can be categorized into three categories, namely variables at the individual level (age, gender, education, etc.)), Employment related variables (status in the main occupation, occupation, etc.) and variables at the household level (household composition, number of breadwinners, etc.) [2].

The most intuitive supporting factor of creating poor working conditions is the low wages / salaries received by workers [16]. Low wages / salaries do not allow a person to make ends meet for himself and his family. Low income can be related to variables at the macro level such as regulations regarding minimum wage for workers, and variables related to individuals and occupations they occupy. Although empirically found a weak relationship between minimum wage and poverty, [17] in his research concluded that for minimum wage to have a positive impact on poverty, it must be interacted with employment levels, household size, number of household members who have income, non-salary income, and many other factors. With the same wage, a larger household size will increase the chances of the household becoming poor due to the increasingly difficult to meet the living needs of each household member.

However, the factor of low wages alone do not fully cause someone to be working poor, some other factors related to the demographics of individuals and household factors such as gender, education, race, type of work (parttime or full-time), live in the house a household with only one person earning wage/salary, or living in a household that has children [18], [19] is considered to be associated with a person's chance to become a poor worker. Low education limits one's choices for the type of work that can be taken, and is often associated with low status in employment so that the income received also tends to be low [20].

Despite the low wage factor is the most intuitive supporting factors, it should be underlined also that poverty is not always synonymous with worker with low wages/salaries. The poor worker refers more to a "conditions" and is influenced by household characteristics rather than individual conditions [21]. A worker may have a low wage, but if he has a spouse or other household member who also works and has an income, the combined income can exceed the official poverty line and lift the household and its members from poverty status.

An empirical study by Losa \& Soldini (2011) on poor workers in seven regions in Switzerland revealed that apart from differences in social, political and economic terms, as well as poverty levels of workers, the main risk factor for worker poverty is household size (number people living in the household), number of hours worked, level of education, and citizenship. The number of breadwinners in the household also affects the worker poverty. Individuals living in households that only have one breadwinner while other household members, especially those of working age, do not work and generate income will have the opportunity to live below the poverty line [23]. Řimnáčová \& Kajanová (2019) explained in his research that according to the European Commission, there are four key factors that influence whether workers with low incomes will be classified as poor workers, namely (1) whether the worker works part-time or full-time and whether the work is stable within a year, (2) whether in the household there is a breadwinner besides himself, (3) household expenses and the number of dependents in the family, especially children, and (4) taxes and the existence of transfers (assistance) from the government.

Without ruling out the influence of macro-level variables, this studyare focused on descriptive analysis of the micro-level variables in relation with the creation of a mechanism of working poor situation and draw up profiles of working poor in Indonesia.

\section{METHOD}

In order to meet the research objective of knowing the characteristics of working poor in Indonesia, this study utilizes data from the results of the National SocioEconomic Survey (Susenas) conducted by the Badan Pusat Statistik (BPS) in March 2018. Susenas collects reliable information on social characteristics and economy of 300,000 respondents covering all provinces throughout Indonesia. From the results of the Susenas, these information can be obtained: the demographic information, education, employment, health, to the household expenditure of respondents. In relation to the objectives, this study limits the analysis of male and female respondents aged 15 years and over (working age) who are in the workforce and are working / temporarily not working at the time of enumeration. 
The concept of working used by BPS in Susenas is to produce goods / services for other people with the aim of obtaining / helping to earn a minimum income for 1 (one) cumulative hour in the past week. The approach used in determining poor status in this study refers to the concept used by BPS, namely the inability (in economic terms) to meet the minimum basic needs for food and non-food [8]. The magnitude of the minimum basic needs is manifested in the form of the Poverty Line measure, which contains the amount of the expenditure value of minimum food requirements (which is equivalent to 2100 kilocalories per capita per day) and minimum non-food needs (such as housing, clothing, health, and education). A person is said to be poor if the per capita expenditure of the household is below the magnitude of the specified poverty line, the magnitude is different each year, and is also different for each province and the classification of residence (urban / rural).

The study used the descriptive analytical approach that emphasizes the cross tabulation between variables thought to be characteristic of the working poor are the focus of research. Variables used include: gender, age of workers, highest level of education completed, status of workers in main work, total hours worked, business field, household size, number of household members who work and have an income.

\section{RESULT AND DISCUSSION}

\section{A. The Profile of Working Poor in Indonesia}

By looking at the conditions in Table 1 which are still marked by the condition of the majority of the population working with elementary school education and below, the status of informal workers, and one third of the total workers working in the agricultural sector. Indonesia's employment conditions in 2018 are still overshadowed by the large potential for creating poor workers due to the low wages received by workers. The characteristics mentioned above are factors which according to the research are strong enough to determine whether a person who works is classified as poor or not.

Table 2 shows a comparison between the profiles of poor and non-poor workers in Indonesia with regard to variables at the individual level, variables related to work, and variables at the household level based on Susenas March 2018 results. There are no differences in the sex characteristics between poor workers and poor workers, but male workers are more likely to be poor workers compared to female workers. However, poor workers tend to be in the older age group when compared to non-poor workers. Low education is still the main characteristic of poor workers, around 65 percent of poor workers only complete their education in primary school or do not graduate at all, in contrast to non-poor workers who have higher levels of education. More than 60 percent of the working poor live in rural areas. This is because there are not many employment options available in the village. In addition, work in villages is usually synonymous with work related to agriculture that has low wages.

It should be noted that many of the working poor are still in prime age for work (15-35). Young workers have lower wages / salaries so that they are more likely to become poor workers, this may be related to the lack of experience they have so they have a low position in employment and do not yet have the bargaining power to increase their incomes. But the bright side of this condition is there is still much potential to increase income if they have access to jobs with better chance of wages/salaries.

$$
\text { TABEL } 1 .
$$

THE PROFILE OF WORKING POPULATION IN INDONESIA, 2018

\begin{tabular}{|c|c|c|}
\hline \multicolumn{2}{|c|}{ Characteristics } & \multirow{2}{*}{$\begin{array}{c}\begin{array}{c}\text { Percentage } \\
(\mathbf{n}=\mathbf{1 2 3 . 3 6 8 . 8 2 3})\end{array} \\
62,68\end{array}$} \\
\hline Gender & Male & \\
\hline & Female & 37,32 \\
\hline \multirow[t]{2}{*}{ Type of Residence } & Rural & 46,36 \\
\hline & Urban & 53,64 \\
\hline \multirow[t]{5}{*}{ Level of Education } & $\leq$ Primary School & 43,60 \\
\hline & Junior High School & 17,46 \\
\hline & $\begin{array}{l}\text { Senior High } \\
\text { School }\end{array}$ & 27,85 \\
\hline & Diploma & 2,93 \\
\hline & $\mathrm{S} 1 / \mathrm{S} 2 / \mathrm{S} 3$ & 8,16 \\
\hline \multirow[t]{3}{*}{ Sector } & Agriculture & 30,51 \\
\hline & Manufacture & 12,94 \\
\hline & Others & 56,55 \\
\hline \multirow[t]{2}{*}{ Status of Worker } & Formal & 45,40 \\
\hline & Informal & 54,60 \\
\hline
\end{tabular}

Source: Authors' calculation based on Susenas March 2018 data weighted

Around 3 out of 4 poor workers are informal workers, which in terms of income tends to be less stable compared to formal workers. There is an assumption that poor workers arise due to the feeling of laziness from workers which is marked by the lack of time spent working. This is not entirely true, only one third of the working poor have less than normal working hours ( 35 hours a week), while even more than half of the working poor have worked more than normal hours (above 40 hours a week). The pattern of working hours for poor workers is not much different from the pattern of working hours for non-poor workers. Meanwhile, the agricultural sector is still a "granary" of poor workers, the majority of poor workers come from workers who work in the agricultural sector (see Figure 1). This is supported by the fact that the population who work in the agricultural sector is usually a free worker whose income level is uncertain. In addition, many are family / unpaid workers, who although in practice help with work and help in earning income, they do not directly provide additional income to households.

Most of the poor workers come from households with a single breadwinner, meaning that only one member of the household works and earns income. In contrast to non-poor workers, most households of non-working poor are supported by more than one breadwinner. The number of household members becomes important especially when compared to the size of the household, meaning that many household members live together with the breadwinner. With the same number of breadwinners and the same amount of income, a greater number of household 
members will certainly put a greater burden on the breadwinner because there are more people who have to meet their daily needs. The existence of highly dependent household members such as toddlers can also cause a

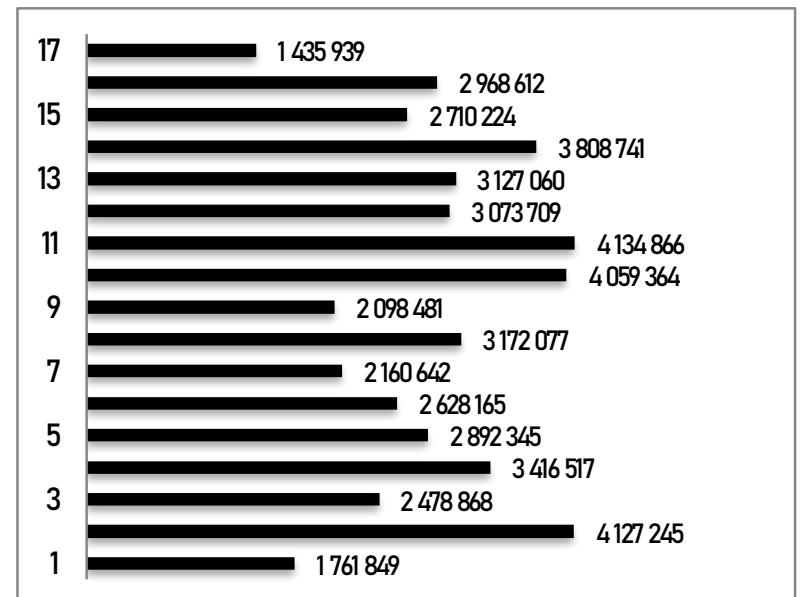

Figure 1.Mean Wage/Salary of Workers by Sectors in Indonesia (Rupiahs), 2018

Source: Sakernas February 2018 data, processed

Notes:

\begin{tabular}{|c|c|}
\hline 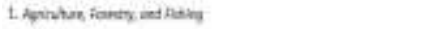 & 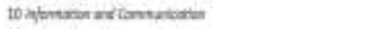 \\
\hline 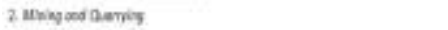 & II thevid wit hurnor dotiven \\
\hline I Wmatertaits & II Mailumentaves \\
\hline 4 eterterped on Say & Ladies tentes \\
\hline 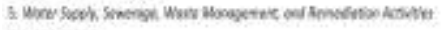 & 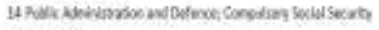 \\
\hline E. costurten & IS rexules: \\
\hline 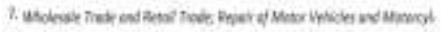 & 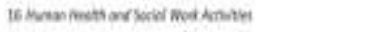 \\
\hline 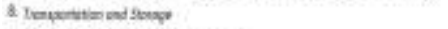 & 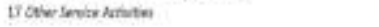 \\
\hline
\end{tabular}

worker to become a poor worker. The greater the number of children under five, the more likely a person is to become a working poor. In addition to dealing with food and non-food needs of members of households with high dependency that need to be met.

The presence of toddlers can also affect the allocation of time owned by other family members, especially women as their mothers. The existence of a toddler makes the time owned by his mother increasingly taken up for the needs of caring for the toddler, so that the time previously available for work decreases. Some women withdraw from the job market when they have a toddler who must be taken care of at home. This in turn is also related to the number of breadwinners in a household, leaving the mother from work places a greater burden on the head of the household / other household member earning a living because the breadwinner is reduced and the household members who become dependents increase, so raises greater potential to become a working poor.

\section{B. Policy Implication}

The results of the descriptive analysis of this study indicate that the risk of becoming a poor worker increases partly because workers have a low level of education so that not many types of work with various levels of wages can be chosen by these workers, and ultimately forced to take any job even though the income generated is low. Encouraging existing workers to return to school and improve their education is a policy that is less effective, but it still needs to be done in future generations. What the government can do is to improve the skills of existing workers so they have higher bargaining power and have more choices in terms of employment. Another thing that is important to note further on education and its relationship with the status of the working poor are the children of the working poor also have to fight harder to get a decent and higher education. While achieving the higher education level is important to improve the lives of the working poor and their families [25], it also can reduce the incidence of living in poverty [26]. The educational opportunities available to them are not the same as those of the children of non-poor workers. Although it does not fully guarantee they will not become working poor, without higher education, they will still face the same risks as their parents with low education who become working poor.

With the high number of workers in the agricultural sector having poor working status, the government needs to pay more attention to this sector. Although a lot of budget has been spent on the agricultural sector, in fact this sector is still a "pocket" of poverty for the working population. The government needs to boost modernization in the agricultural sector, which has traditionally been more traditionally managed.

The risk of being a poor worker in Indonesia is also related to the condition of being the only household member who earns a living, one of which is caused by women leaving their jobs because of being a mother. The government needs to pay attention to this by providing policies that can support a mother to continue working without ignoring her duties to care for children, for example to reduce the burden of a mother's worries in caring for her child, the government can provide a public day care that is guaranteed to be safe and with affordable cost.

Some previous studies suggest that the government contributes in the form of setting minimum wages, the amount of which ensures the fulfillment of the needs of decent living for workers. This is not fully applicable in Indonesia because the employment conditions are dominated by informal workers, so the application of minimum wage regulations will not achieve its objectives.

\section{CONCLUSION}

Like other countries in the world, both developed and developing countries, Indonesia still faces the problem of working poor, and this condition is likely to continue to exist and has the potential to continue to increase if the government does not make policies to reduce the risk of its population becoming poor workers. From the processing of Susenas data from March 2018, we can obtain profiles / characteristics of poor workers in Indonesia. Male sex, living in rural areas. Still in prime age range, but poorly educated, only at elementary school level or less, are characteristic of poor individual workers in Indonesia. These characteristics at the individual level are closely related to the mechanism of low wages which makes a person more at risk of becoming a working poor.

From the working hour side, poor workers in Indonesia break the notion that poverty is caused by feeling lazy to work, this is indicated by only one third of the working poor who have working hours under normal working hours, while more than half work working hours exceeding normal working hours (over 40 hours during the week). From this it can be said that being a poor worker is not solely due to lack of working hours, but because the wages 
received from work remain low even with working hours that have exceeded normal working hours. With the provision of low education, many of the workers in Indonesia are informal workers. Some characteristics of informal workers are low average wages and long periods of unstable employment. These characteristics also become the characteristics of employment in the agricultural sector, so that the working poor in Indonesia are the most scattered in this sector compared to other existing sectors.

Although it is a kind of key factor for the emergence of poor workers in Indonesia, low wage rates "need" to interact with other factors to cause a worker to become a poor worker. Being the only breadwinner in the household, while many other household members who do not work as dependents, especially toddlers, will increase the risk of a worker becoming a poor worker. The government is expected to pay more attention to the phenomenon of the working poor, and not get caught up in the short-term goal of creating as many jobs as possible without taking into account that the work must also guarantee the rights of workers to live properly and obtain welfare.

The government is expected to pay more attention to this phenomenon of the working poor, and not get caught up in the short-term goal of creating as many jobs as possible without taking into account that the work must also guarantee the rights of workers to live properly and obtain welfare.

\section{REFERENCE}

[1] J. Priebe, F. Howell, and V. A. Sari, "Poverty and The Labor Market in Indonesia - Employment Trends Across The Wealth Distribution," no. October, 2014.

[2] K. C. K. Cheung and K. L. Chou, "Working Poor in Hong Kong," Soc. Indic. Res., vol. 129, no. 1, pp. 317-335, 2016.

[3] World Bank, World Development Report 2013. Washington DC: The World Bank, 2013.

[4] M. Mathew and I. Y. H. Ng, "Coping Through Reproducing State Ideology: Working Poor Families in Singapore," Glob. Soc. Welf., vol. 3, no. 4, pp. 269-277, 2016.

[5] J. Feder and D. Yu, "Employed yet poor: low-wage employment and working poverty in South Africa," Dev. South. Afr., vol. 0, no. 0, pp. 1-19, 2019.

[6] R. Gammarano, "The working poor or how a job is no guarantee of decent living conditions," Spotlight Work Stat., no. April, 2019.

[7] E. Priyono, "Jurnal Ekonomi dan Kewirausahaan Vol 1, No. 2, Juli 2002.," J. Ekon. dan Kewirausahaan, vol. 1, no. 2, pp. 1-14, 2002.

[8] Badan Pusat Statistik, "Penghitungan dan Analisis Kemiskinan Makro di Indonesia," 2018.

[9] World Bank, World Development Report 2000/2001: Attacking Poverty, no. September. 2000

[10] H. K. Lui, "Widening income distribution in post-handover Hong Kong," Widening Income Distrib. Post-Handover Hong Kong, no. June 2012, pp. 1-146, 2013.

[11] W. Strengmann-Kuhn, "Working Poor in Europe: A Partial Basis Income for Workers?," SSRN Electron. J., no. September, 2005.

[12] N. Majid, "The size of the working poor population in developing countries," Employ. Pap., vol. 16, no. May, p. 2, 2001

[13] E. Crettaz and G. Bonoli, "Why are Some Workers Poor? The Mechanisms that Produce Working Poverty in a Comparative Perspective," SSRN Electron. J., 2012.

[14] A. Goerne, "A Comparative Analysis of In-Work Poverty in the European Union," Work. Poverty Eur., pp. 15-45, 2011.

[15] H. Lohmann, "Welfare states, labour market institutions and the working poor: A comparative analysis of 20 european countries," Eur. Sociol. Rev., vol. 25, no. 4, pp. 489-504, 2009.

[16] B. Nolan and I. Marx, "Low Pay and Household Poverty," Labour Mark. Inequalities Probl. Policies Low-Wage Employ. Int. Perspect., no. 216, 2000.

[17] G. J. Stigler, "The Economics of Minimum Wage Legislation," Am. Econ. Rev., vol. 36, no. June, pp. 358-365, 1946.
[18] E. Crettaz, "A state-of-the-art review of working poverty in advanced economies: Theoretical models, measurement issues and risk groups," J. Eur. Soc. Policy, vol. 23, no. 4, pp. 347-362, 2013

[19] L. Kenworthy and I. Marx, "Discussion Paper Series In-Work Poverty in the United States," no. 10638, 2017.

[20] T. a. Julian and R. a. Kominski, "Education and Synthetic WorkLife Earnings Estimates," Census Bur., no. September, pp. 1-14, 2011.

[21] L. Pradella, "The working poor in Western Europe: Labour, poverty and global capitalism," Comp. Eur. Polit., vol. 13, no. 5, pp. 596-613, 2015.

[22] F. B. Losa and E. Soldini, "The Similar Faces of Swiss Working Poor," Swiss J. Econ. Stat., vol. 147, no. 1, pp. 17-44, 2011.

[23] K. Orsini, F. Buchel, and A. Mertens, "Is mothers' employment an effective means to fight family poverty? Empirical evidence from seven European countries," Luxemb. Income Study Work. Pap. Ser., no. 363, pp. 1-25, 2003.

[24] Z. Řimnáčová and A. Kajanová, "Stress and the working poor," Hum. Aff., vol. 29, no. 1, pp. 87-94, 2019.

[25] C. McSwain and R. Davis, "College Access for the Working Poor: Overcoming Burdens to Succeed in Higher Education," p. 43, 2007.

[26] B. W. Klein and P. L. Rones, "A Profile of the Working Poor.," Mon. Labor Rev., vol. 112, no. 10, pp. 3-13, 1989. 
IPTEK Journal of Proceedings Series No. 6 (2019), ISSN (2354-6026)

The $1^{\text {st }}$ International Conference on Global Development - ICODEV

November $19^{\text {th }}, 2019$, Rectorate Building, ITS Campus, Sukolilo, Surabaya, Indonesia

TABLE 2. The PROFILE OF Working PoOR AND NON WORKING POOR IN INDONESIA, 2018

\begin{tabular}{|c|c|c|c|}
\hline \multicolumn{2}{|c|}{ Characteristics } & $\begin{array}{c}\text { Non Working Poor } \\
(\mathrm{n}=113.186 .917)\end{array}$ & $\begin{array}{l}\text { Working Poors } \\
(\mathrm{n}=10.181 .906)\end{array}$ \\
\hline \multicolumn{4}{|l|}{ Individual level variables } \\
\hline \multirow[t]{2}{*}{ Gender } & Male & 62,70 & 62,37 \\
\hline & Female & 37,30 & 37,63 \\
\hline \multirow[t]{2}{*}{ Type of Residence } & Rural & 44,80 & 63,66 \\
\hline & Urban & 55,20 & 36,34 \\
\hline \multirow[t]{6}{*}{ Age Group } & $15-24$ years old & 13,42 & 13,56 \\
\hline & 25-34 years old & 24,33 & 22,21 \\
\hline & $35-44$ years old & 24,84 & 25,01 \\
\hline & 45-54 years old & 20,74 & 18,01 \\
\hline & 55-64 years old & 11,84 & 12,69 \\
\hline & $\geq 65$ years old & 4,83 & 8,52 \\
\hline \multirow[t]{5}{*}{ Level of Education } & $\leq$ Primary School & 41,62 & 65,59 \\
\hline & Junior High School & 17,42 & 17,95 \\
\hline & Senior High School & 29,02 & 14,88 \\
\hline & Diploma & 3,16 & 0,44 \\
\hline & $\mathrm{S} 1 / \mathrm{S} 2 / \mathrm{S} 3$ & 8,78 & 1,14 \\
\hline \multicolumn{4}{|l|}{ Work-related variables } \\
\hline \multirow[t]{3}{*}{ Total working hours } & $1-35$ hours & 21,73 & 33,06 \\
\hline & $35-40$ hours & 14,85 & 15,36 \\
\hline & $>40$ hours & 63,42 & 51,58 \\
\hline \multirow[t]{2}{*}{ Status of Workers } & Formal & 46,99 & 27,85 \\
\hline & Informal & 53,01 & 72,15 \\
\hline \multicolumn{4}{|l|}{ Household level variables } \\
\hline \multirow[t]{3}{*}{ Number of Breadwinner in the Household } & 0 & 0,23 & 0,41 \\
\hline & 1 & 32,51 & 41,38 \\
\hline & $\geq 2$ & 67,26 & 58,22 \\
\hline \multirow[t]{4}{*}{ Number of Dependants in the Household } & 0 & 11,19 & 3,49 \\
\hline & 1 & 23,79 & 11,16 \\
\hline & 2 & 28,96 & 20,30 \\
\hline & $\geq 3$ & 36,06 & 65,05 \\
\hline \multirow[t]{3}{*}{ Number of Toddlers in the Household } & 0 & 70,44 & 52,99 \\
\hline & 1 & 25,92 & 38,03 \\
\hline & $\geq 2$ & 3,64 & 8,98 \\
\hline
\end{tabular}

Source: Authors' calculation based on Susenas March 2018 data, weighted 


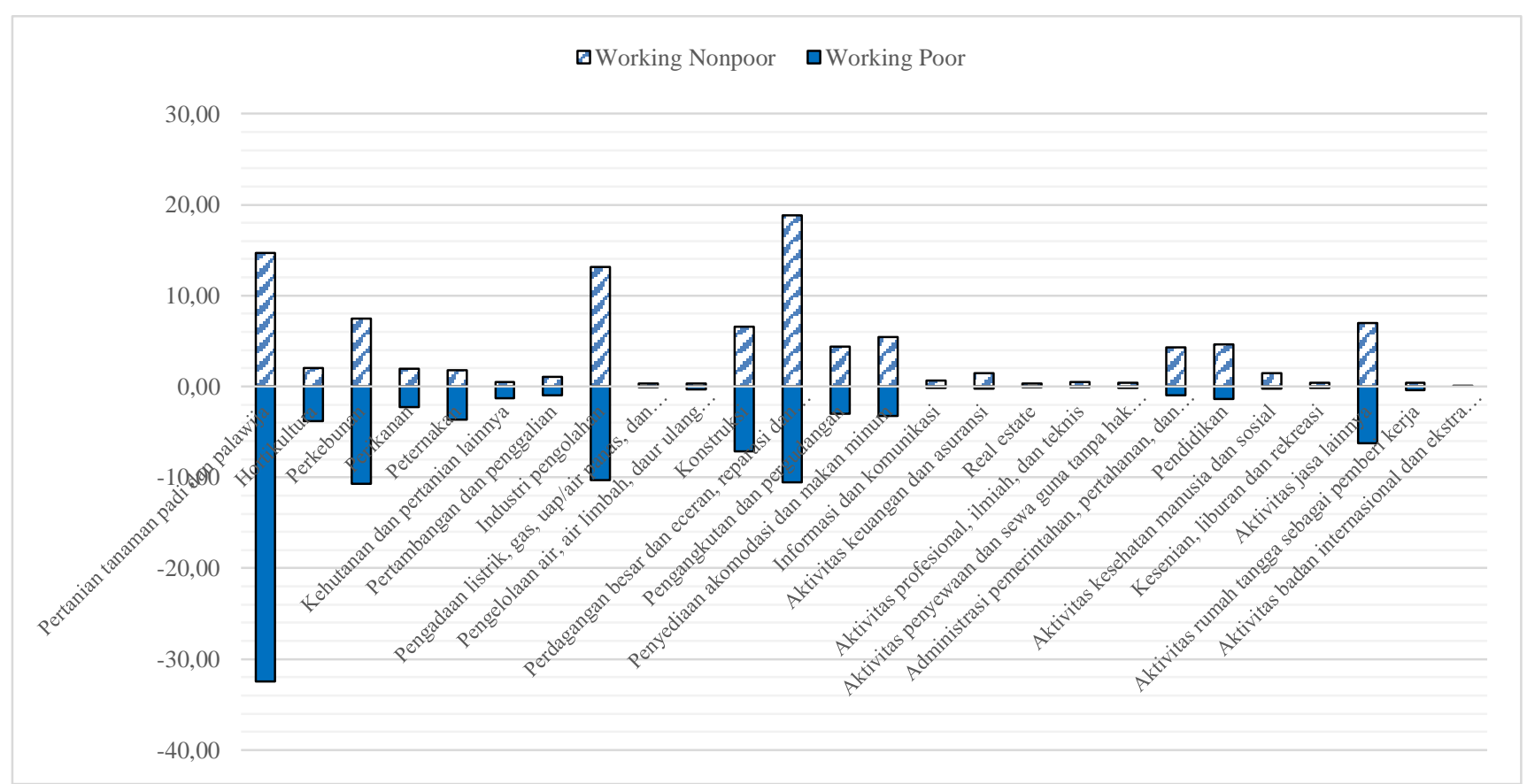

Figure 2. Percentage of Working Poor and Non Working Poor by Sectors in Indonesia, 2018 Source: Authors' calculation based on Susenas March 2018 data, weighted 